\subsection{Laborraum}

- Chemie-Labor-Schrank mit Abzugshaube

- Glovebox für Arbeiten in definierter Atmosphäre

- Selbst entwickelte Bildaufnahme- und -verarbeitungsanlage „Dynamic Imaging of Solidification (DioS)" mit CCD-Kamera, Mikro-Bridgman-Ofen und Software zur simultanen Aufnahme von Bildern/Videos und Temperaturdaten

- Particle Image Velocimeter (Dantec Dynamics 3D Stereoscopic PIV System)

\subsection{Lehr- und Schulungsraum}

- 9 Bildschirmarbeitsplätze, ein Präsentations-PC

- FLUENT (CFD-Programm)

- MAGMASoft (Software: Formfüllung und Erstarrung)

- ABAQUS (Software: Spannung und Verformung)

- CALCOSoft (Software: Strangguss)

\subsection{Serverraum}

- High-performance Linux-based PC-Cluster with cluster server and 32 nodes

- Shared Memory Workstation with 16 nodes (SGI Altix 350)

- 3 server machines ( Primary, W2k, web)

- Linux firewall

- Backup for Primary server and Linux firewall

- 15 IBM-compatible PC's

- 1 Silicon Graphics Workstation Octane

- 2 Acer Notebooks Aspire 1403LC bzw. 1406LC

- 1 Toshiba Notebook Satellite Pro

\section{Ausgewählte Veröffentlichungen}

Wu, M., und A. Ludwig: A 3-phase model for mixed columnarequiaxed solidification. Metall. Mater. Trans. A, (2006), in print. - Wu, M., und A. Ludwig: Recent developments on deterministic models for the columnar-to-equiaxed transition (CET). Metall. Mater. Trans. A, (2006), submitted. - Eck, S., J. Mogeritsch und A. Ludwig: Experimental observation of convection during equiaxed solidification of transparent alloys. Mater. Sci. Forum, 508 (2006), 157-162. - Wu, M. A. Ludwig und J. Luo: Numerical study of the thermal-solutal convection and grain sedimentation during globular equiaxed solidification. Mater. Sci. Forum, 475-479 (2005), 2725-2730. - Wang, T., M. Wu, A. Ludwig, M. Abondano, B. Pustal und A. Bührig-Polaczek: Modelling the thermosolutal convection, shrinkage flow and grain movement of globular equiaxed solidification using a three phase model. Int. J. Cast Metals Research, 18 (2005), 221228. - Pfeiler, C., M. Wu und A. Ludwig: Influence of argon gas bubbles and non-metallic inclusions on the flow behavior in steel continuous casting. Mat. Sci. Eng. A, 413-414 (2005), 115-120. - Ludwig, A., M. Gruber-Pretzler, F. Mayer, A. Ishmurzin und $M$. Wu: A way of coupling ternary phase diagram information with multiphase solidification simulations. Mat. Sci. Eng. A, 413-414 (2005), 485-489. - Ludwig, A., und M. Wu: Modelling the columnar-to-equiaxed transition (CET) with a 3 phase Eulerian approach. Mat. Sci. Eng. A, 413-414 (2005), 109-114. - Wu, M., und A. Ludwig: Study of spatial phase separation during solidification and its impact on the formation of macrosegregations. Mat. Sci. Eng. A, 413-414 (2005), 192199. - Kharicha, A., A. Ludwig und M. Wu: Shape and stability of the slag/melt interface in a small DC ESR process. Mat. Sci. Eng. A, 413-414 (2005), 129-134. - Wu, M. A. Ludwig, M. Pelzer und U. Postl: On the impact of macroscopic phase separation on solidification microstructures. Adv. Eng. Mat., 7 (2005), 846-891.

\title{
Berichtigung
}

In Heft 5 auf Seite 208 (Artikel Gruber, Wallner, BuderStroisznigg, Strauß, Jandel, Lang) ist ein Fehler aufgetreten. Die Abbildung 3 ist falsch und muss durch die folgende ersetzt werden. Die Abbildungsunterschrift ist richtig.

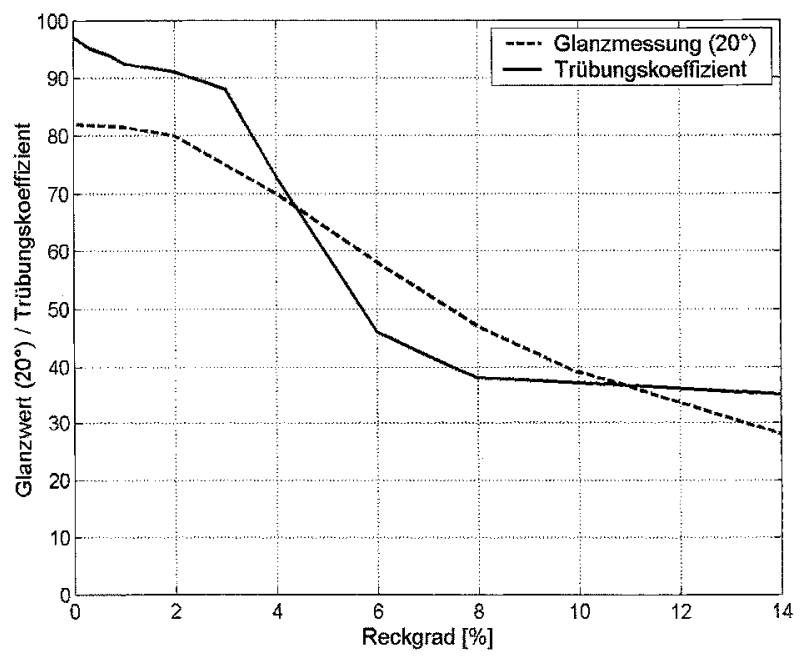

Abb. 3. Fotografisch bestimmter Trübungskoeffizient der bandbeschichteten Blechproben im Vergleich zum Glanzwert als Funktion des Reckgrades 